\title{
ЋИРИЛИЦА И ЛАТИНИЦА У БЕЛОРУСИЈИ: ИСТОРИЈА И САВРЕМЕНО СТАЬЕ
}

\begin{abstract}
У раду су анализирани фактори који су утицали на избор писма у Белорусији током њене историје све до данас: изворност писма, средњовековна традиција, контакти и страни утицаји (западни и источни), државна политика, став интелектуалаца, као и однос народа према свом писму. Ћирилица представља изворно писмо Белоруса од почетка рукописне традиције, као и писмо првих белоруских штампаних књига Франциска Скарине. Међутим, географски положај Белорусије између православног и католичког света условио је преплитање различитих утицаја и традиција током историје земље, односно коришћење и ћирилице и латинице. Писмо као важан део културно-историјског идентитета представљало је и представља инструмент ширења утицаја, као и средство супротстављања одређеном утицају, средство одвајања од доминантне традиције.
\end{abstract}

1. Република Белорусија (званично: Република Беларус, у складу са називом на белоруском: Рэспубліка Беларусь) према члану 17 Устава има у службеној употреби два језика: белоруски и руски. Према Уставу из 1994. године Белорусија је имала један државни језик: белоруски, међутим, након републичког референдума 1996. године донете су измене и допуне Устава, укључујући увођење два службена језика: белоруског и руског. Тренутно руски језик доминира у већини сфера урбаног живота.

Оба језика, и руски и белоруски, користе ћирилицу, уз одређене разлике у азбуци. ${ }^{1}$ Током историје у Белорусији, међутим, поред ћирилице присутно је и коришћење латинице. Циљ овог рада је резимирање најважнијих чиње-

\footnotetext{
*svetlanagoljak@yahoo.co.uk

${ }^{1}$ Белоруска азбука има само десетерично слово $i$ које се у руској азбуци више не користи, као и специфично слово ў (упор. рус. пожалуйста - бел. калі ласка, рус. любовь - бел. любой и каханне, рус. чудесно - бел. иудоўна, рус. спасибо - бел. дзякуй, рус. очень приятно - бел. вельмі прыемна, рус. друг и подруга - бел. сябар и сяброўка итд). У белоруском правопису, за разлику од руског, заступљен је фонетски принцип писања самогласника (нпр. рус. молоко - бел. малако итд).
} 
ница у вези са употребом оба писма у Белорусији, а пре свега разматрање пресудних фактора који су одредили чврст положај ћириличног писма у савременој држави.

Ова питања су тесно повезана са питањима националног идентитета и државног развоја, јер „као што је познато, писмо иде одмах после вере и од свих језичких феномена има највећу културно-историјску функцију. Писмо је знак националне и верске самоидентификације једног народа" (Мячкоўская 2005: 35).

2. Ћирилица, традиционална за православне Словене, везује се како за почетак белоруске рукописне традиције тако и за прве белоруске штампане књиге које је у 16. веку израдио белоруски просветитељ Франциск Скарина. У својим књигама Скарина је у духу ренесансне традиције мало променио изглед неких ћириличних слова, учинивши их „округлијим и лакшим”, а текст „светлијим и провиднијим”; такође је поједноставио састав азбуке, предухитривши за два века реформу руске ћирилице Петра Великог (1710) (Мячкоусская 2005: 35-36).

У средњовековној држави Велика кнежевина Литванска, ${ }^{2}$ у чији састав је улазио већи део белоруских земаља, на основу централних белоруских говора и црквенословенске традиције створен је књижевни језик на којем је у периоду 14-16. века састављена већина државних, правних и пословних докумената (старобелоруски језик, или западноруски, у другој терминологији). Био је званичан језик Кнежевине све док није забрањен од стране пољског Сејма (парламента) 1696. године. За писање је углавном коришћена ћирилица. Устав Кнежевине је штампан ћирилицом.

Коришћење латинице за записивање белоруских речи почело је крајем 16. века због потребе да се белоруски цитати укључе у зборнике на латинском или пољском језику. Радило се о незваничној употреби латинице, уз примену пре свега правила пољског језика. Коришћење латинице, паралелно са ћирилицом, проширило се током 17. века и наставило се у 18. веку. Након уније Кнежевине са суседном Пољском (1569) отворене су бројне римокатоличке црквене школе. Према речима Нине Мечковске, тада су „Белоруси познавали латиницу због традиције образовања на латинском”, као и захваљујући упознавању са културом Литванаца. Многи Белоруси су били билингвални: активно су говорили и белоруски и пољски језик (Мячкоўская 2005: 36). Шарену слику потврђује и рад штампарија: на пример, у Богојављенској штампарији у белоруском граду Могиљову крајем 17. и током 18. века објављено је 87 издања на ћирилици и 25 на латиници.

Поред ћирилице и латинице, на територији Белорусије су забележени случајеви коришћења и арапског писма (белоруска „арабика”) за преношење живог говора белоруско-литванских Татара који су живели у Великој кнежевини Литванској.

\footnotetext{
${ }^{2}$ У литератури су такође коришћени термини Велика кнежевина Литва (Литванија) и литванско-руска држава (Анђелковић 2009).
} 
Након слабљења и касније губитка самосталности Велике кнежевине Литванске, током дужег периода свог развоја Белорусија се налазила у саставу пољске или руске државе, ${ }^{3}$ према томе се ширио тзв. западни или источни утицај, укључујући употребу латинице или ћирилице, уз ширење католичке вере или православља. Белоруски језик је више пута забрањиван у 17,18 . и 19. веку. Писмо је представљало управо инструмент ширења утицаја, као и средство супротстављања једном или другом утицају, средство издвајања у односу на традицију која тренутно доминира.

3. Током 19. и почетком 20. века у Белорусији су присутна оба писма, што је условило сложену ситуацију двадесетих година 20. века, када се одлучивало о даљем развоју белоруског језика. Издвојићемо одређене чињенице у вези са избором једног или другог писма у издавању дела значајних писаца и песника, као и у делатности првих новина; а касније и у првим граматикама и речницима белоруског књижевног језика.

3.1. Током 19. века се појавио цео низ пољско-белоруских писаца који су писали пре свега на пољском, али и на белоруском језику: Јан Чачот, Јан Баршчевски, Александар Рипински, Винцент Дунин-Марцинкевич, Винцент Каратински, Владислав Сиракомља, Адам Гуринович и други. Проучавали су белоруску народну културу, систематизовали фолклор, објавили разне студије о Белорусији, а своја дела су писали и објављивали на латиници (или углавном на латиници и делимично на ћирилици). На латиници су објављивана и дела важног идеолога белоруског националног препорода, Францишака Багушевича.

Почетком 20. века су и прве збирке песама белоруских песника, који су одиграли важну улогу у стварању књижевног језика, изашле како на ћирилици тако и на латиници. Доминирала је ћирилица, али је било и других примера. Тако, песникиња Цјотка је објавила на латиници две збирке песама, као и прву читанку за децу (бел. „Першае чытанне для дзетак-беларусаў”, 1906). Другу читанку за децу је написао Јакуб Колас, латиницом, а објављена је на ћирилици (бел. „Другое чытанне для дзяцей беларусаў”, 1910) (Белакурская 2005). Прва збирка поезије Јанка Купале је објављена на ћирилици (бел. „Жалейка” - народни музички инструмент попут фруле, 1908), док је друга збирка „Гуслар” изашла на латиници („Huślar”, 1910). Максим Богданович је своју збирку поезије 'Венац' објавио на ћирилици (бел. „Вянок”, 1914). На корицама тог издања се налазио списак књига које су се могле наручити у издавачкој кући: од укупно 88 издања било је 44 на ћирилици, 20 на латиници, 16 на оба писма.

3.2. Традиција издавања белоруских новина на латиници почиње од револуционара и касније вође устанка из 1863-1864. Кастуса Калиновског, који се залагао за идеје националног и социјалног ослобођења Белорусије и њеног самосталног развоја. Калиновски је током две године (1862-1863) издавао у Вилњи нелегалне белоруске новине на латиници, укупно седам

${ }^{3}$ У 16. веку након Лублинске уније између Велике кнежевине Литванске и Пољске ствара се држава Реч Посполита (1569-1795), током 17. и 18. века Белорусија је у саставу Речи Посполите; у 19. веку је у саставу царске Русије; у 20. веку је у саставу СССР-а; при томе је западна Белорусија била у саставу Пољске 1921-1939. године. 
бројева: „Мужыцкая праўда” (досл. 'Сељачка правда/истина'; у оригиналу: „Mużyckaja prauda”).

Почетком 20. века су излазиле књижевне новине око којих су се окупили интелектуалци, представници националног покрета и у којима су објављивана књижевна дела на белоруском језику: новине бел. „Наша доля” (досл. 'Наша судбина') излазиле су током 1906. године на латиници, док су новине „Наша њива” у периоду 1906-1912. излазиле на оба писма, а касније, 19131915. године само на ћирилици.

Издавачка кућа бел. „Загляне сонца і ў наша ваконца” (досл. 'Загледаће сунце и у наше прозорче') извршила је модернизацију белоруске латинице и објавила 1907. године нову абецеду коју су прихватиле друге белоруске издавачке куће (бел. «нашаніўская лацінка», тј. латиница новина „Наша њива”).

Према мишљењу Ивана Лепешева, објављивање књижевних дела и новина латиницом било је делимично условљено забраном цара Александра Другог да књиге и новине излазе на белоруском језику (Лепешаў 2005: 37). Истовремено, то је ипак представљало и свестан избор издавача, као и читалаца. Иван Лепешев, као и други истраживачи, такође помиње анкету коју је спровела „Наша њива” 1911-1912. године, пре него што се због материјалних потешкоћа определила за једно писмо: већина учесника анкете, укључујући Јанка Купалу, изабрала је ћирилицу (Лепешаў 2005: 37).

Према подацима које наводи Жана Белокурска, почетком двадесетог века је било објављено 262 издања на белоруском језику, од њих у периоду 1801-1905. године 22 на ћирилици и 27 на латиници, док у периоду 19061917. године 129 на ћирилици и 84 на латиници (Белакурская 2005: 44).

Ипак, изложене чињенице указују да ситуација у вези са избором једног писма приликом кодификације норми белоруског језика током двадесетих година 20. века није била једноставна. Та ситуација треба да се посматра у ширем контексту друштвених збивања.

4. Нови фактор у 20. веку представљало је формирање нове државе и нове језичке политике. Прво је проглашена Белоруска Народна Република (25. 03. 1918), онда је након доласка бољшевика на власт проглашена Белоруска Совјетска Социјалистичка Република (1. 01. 1919), уз касније одвајање Западне Белорусије која је на основу мировног споразума у Риги 18. 03. 1920. ушла у састав Пољске где је била све до 1939. године.

У новој држави током двадесетих година активно је спровођена политика белорусизације, односно државне подршке белоруског језика и културе, све до промене језичке политике СССР-а крајем двадесетих и тридесетих година и стаљинистичких чистки.

У декларацији о независности БССР, донете 1920. године, као и касније у Уставу из 1927. године, проглашена су четири државна језика као равноправна: белоруски, руски, јеврејски и пољски, с тим што је белоруски језик имао предност у државним установама. Сваки запослени у државним органима био је у обавези да влада руским и белоруским језиком. Било је препоручено да се службена преписка обавља на белоруском језику, при чему су све државне установе добиле рок 1-3 године да то реализују. Према 
статистици, пре 1925. године је само 25\% државних службеника користило белоруски језик, док их је 1927. године било већ 80 \% (Парашкоў 2003: 265).

Отворене су бројне школе - водила се борба против неписмености, као и многе друге образовне институције, укључујући Белоруски државни универзитет (1921). До 1928. године $80 \%$ школа је прешло на белоруски језик. ${ }^{4}$ Отворене су школе и разреди за националне мањине, тако да се настава водила на осам националних језика. Руски и белоруски језик су били обавезни предмети у свим школама (Парашкоў 2003: 264).

Реализација такве политике је захтевала језичке реформе и кодификацију норми белоруског језика.

Први правописни приручници, речници и граматике су изашли на латиници: приручник Антона Луцкевича „Jak prawilna pisać pa biełarusku” (1917), као и приручник Рудолфа Абихта и Јана Станкевича „Pròsty spòsab stàcca ŭ karòtkim čàse hràmatnym” (1918), „Biełaruski prawapis” Антона Луцкевича и Јана Станкевича (1918) и др. Сваки нови приручник, према речима Але Кожинове, давао је нове предлоге преуређења латинице (Кожинова 2017: 3).

Од граматика је најзначајнија била „Белоруска граматика за школе” Бранислава Тарашкевича, који је систематизовао важне карактеристике белоруског језика, укључујући фонетски принцип писања самогласника. Граматика је објављена 1918. године на латиници („Biełaruskaja hramatyka dla škoł”) и мало касније, исте године, на ћирилици; поменућемо и пето издање граматике Бранислава Тарашкевича у којем је дорађена латиница (1929).

Од великог значаја је било оснивање 1922. године Института белоруске културе (Инбелкулта), који је започео опширнија истраживања белоруског језика и реформу белоруског правописа. Институт је 1926. године организовао Академску конференцију о реформи белоруског писма и правописа. На бази Инбелкулта је 1928. године основана Белоруска академија наука, у чијем саставу је био и Институт за лингвистику.

5. Академска конференција, одржана у Минску 1926. године, чија је главна тема била реформа правописа, представљала је можда најинтересантнији научни форум у историји белоруске лингвистике (Запрудскі 2015: 44). Скуп је трајао читавих осам дана, а пре његовог одржавања водила се широка дискусија у јавности. Размотрена су конкретна правописна питања, пре свега у вези са широм применом фонетског принципа, а главна дискусија је вођена између Јазепа Љосика који се залагао за радикалне промене и представника опрезнијег приступа (Сцјапан Некрашевич, А. Багданович и други). Расправљало се о реформи постојеће ћирилице, наиме увођењу нових слова, укључујући предлог да се преузму слова из српске ћирилице: $\hbar, \hbar$, као и да се слово $\breve{u}$ замени за латинично $j$ (Павле Растаргујев и други).

Пред отварање конференције поднет је предлог да се поред ћирилице уведе и латиница која би, по мишљењу неких научника, омогућила доследнију примену фонетског правописа у белоруском језику и обезбедила чвр-

\footnotetext{
${ }^{4}$ Другачија ситуација је била у Западној Белорусији која је 1921. године ушла у састав Пољске (до 1939): године 1918. тамо је било 89 белоруских школа, док их је до средине двадесетих година остало свега четири (Парашкоў 2003: 255).
} 
шћу везу са Западном Белорусијом, која се тада налазила у саставу Пољске и где се користила латиница. Предлог о томе је саставио Максим Гарецки, а потписало га је око 40 учесника скупа, неки са коментарима: „Сматрам латиницу потребном, али ово питање сада није на дневном реду” (Јакуб Колас); „Начелно сам за увођење латинице, међутим, у овом тренутку се прибојавам да ће допринети полонизацији Западне Белорусије” (Јанко Бјалкевич); „Са великим опрезом" (Сцјапан Некрашевич). Ипак, том предлогу током скупа није дат велики значај (Запрудскі 2015: 51-52).

Сви реферати, расправе и други материјали скупа објављени су као посебно издање наредне 1927. године. Навешћемо неколико цитата из реферата учесника који преносе атмосферу времена, а тичу се њихових ставова о питању коришћења ћирилице или латинице (превод са белоруског - С. Г.).

Јазеп Љосик је нагласио да народ не прихвата и неће прихватити латиницу: „У последње време се све чешће и чешће воде разговори о реформи нашег писма, многи су почели да говоре да зар није боље да прихватимо општеевропско писмо - латиницу. Међутим, с тиме не можемо да се сложимо, иако наши школски уџбеници кажу да белоруски језик има два писма: ћирилицу и латиницу. Немогуће је потпуно прећи на латиницу и ево зашто. Иако је код нас било покушаја да се књиге штампају латиницом, ти покушаји су остали само покушаји. Латиница не може да заживи; књиге штампане латиницом леже на полицама, без употребе, док новине више не покушавају да изађу на латиници" (Гісторыя 2004: 83-84).

Вацлав Ластовски је подсетио скуп на изворност ћириличног писма и његову скоро хиљадугодишњу традицију код Белоруса, рекавши да увођење латинице представља „царски рез на који се може принудити само болесни организам”, док „здрав организам нашег писма не може да се натера на такву операцију" (Гісторыя 2004: 90). Ластовски је назвао увођење латинице непотребним експериментисањем: „Чују се гласови 'за латиницу' зато што латиницом пише цела Западна Европа, јер латиница продире и у Азију, а могуће је да ће временом латиница постати светско писмо. Добро, када цела територија бивше Русије прихвати латиницу, до чега неће доћи без претходног одржавања конференција за које ћемо сазнати, онда ћемо је прихватити и ми. Сваки случај увођења латинице данас представља можда и интересантан експеримент, али нека га други пробају на себи, а ми ћемо боље сачекати и видети шта ће с тим да буде. Посматрачи тог експериментисања ће бити у бољој позицији него они који ће играти улогу заморчади" (Гісторыя 2004: 92).

Након конференције је основана комисија у оквиру Инбелкулта, која је до 1930. године припремила пројекат белоруског правописа. Међутим, он није био прихваћен. Власти су наредиле да се припреми нови пројекат. Савет народних комесара БССР донео је 1933. године уредбу „О изменама и поједностављењу белоруског правописа", што је представљало почетак реформи усмерених на зближавање руског и белоруског језика, ${ }^{5}$ тј. језичке политике

\footnotetext{
${ }^{5}$ Од тада до данас постоје два система белоруског правописа: „наркомовка” (од „народни комесари”) - званични правопис који се, са неким изменама, примењује и данас, са једне стране, и „тарашкевица” (са правописним нормама Бранислава Тарашкевича), са друге стране. „Тараш-
} 
спровођене током постојања СССР-а. Положај ћирилице у Белорусији током периода у СССР-у је додатно учвршћен.

6. На чињеницу да писмо представља важан фактор страног утицаја, као и одвајања од доминантне традиције, указује и језичка политика страних влада у Белорусији. За време Првог светског рата, након што је немачка војска окупирала Западну Белорусију и територију око Вилње, немачка влада је званично признала белоруски језик на латиници. Током 1917. године немачка влада је издавала пасоше на немачком и на белоруском језику латиницом.

За време Другог светског рата, током 1941-1944. године, поново је коришћена латиница у окупираној Белорусији. Алфред Розенберг, нацистички министар окупираних источних територија, иницирао је у децембру 1941. године постепени прелазак белоруских школа и штампе на латиницу; званична уредба је изашла 25. 06. 1942.

7. Након Другог светског рата у Белорусији је коришћена ћирилица, док се латиница појављивала само у издањима белоруске емиграције у Западној Немачкој, САД-у, Великој Британији и Италији. На пример, католички свештеник Петар Татаринович је латиницом објавио 120 бројева теолошког часописа „Źnič” (1950-1975), као и преводе Библије и друге публикације. У Чикагу су изашли часописи „Rada Kruhu”, „Litva”, као и књига Вацлава Пануцевича „Bieraściejskaja vunija” (1972) итд. Јан Станкевич је предложио преуређене верзије белоруске латинице.

Деведесетих година, када је Белорусија постала независна земља, порасло је интересовање за коришћењем латинице. На латиници су изашли неки чланци у новинама „Наша њива”, „Arche” и другим. Један број новина „Наша њива” је у потпуности објављен на латиници (1993).

У данашње време белоруска латиница се користи веома ретко: Белоруси пишу ћирилицом. Латиница је присутна на Интернету, међутим и ту преовлађује ћирилица (сајтови, претраживачи итд). Поруке на мобилним телефонима се неретко пишу латиницом. Ретки су примери књижевних дела на латиници (нпр. белоруски песник Владимир Орлов је 2012. године објавио књигу поезије на оба писма).

Врши се транслитерација личних имена и географских назива, за практичне потребе карата, путоказа итд. У тзв. „навигацији” се примењује Правилник о транслитерацији географских назива Белорусије из 2013. године. Приликом попуњавања анкета за издавање пасоша грађани сами, према свом нахођењу, наводе потребан латинични облик њихових имена и презимена која су написана ћирилицом на једној и латиницом на другој страни пасоша. Такође, одређени произвођачи на етикетама користе оба писма.

8. Ћирилица представља изворно писмо Белоруса од почетка рукописне традиције, као и писмо првих белоруских штампаних књига Франциска Скарине. Међутим, географски положај Белорусије између Русије на истоку и Пољске на западу, између Украјине на југу и балтичких земаља на северу,

кевицу” користи опозиција. Разлике се тичу писања неакцентованих самогласника, асимилационе мекоће сугласника, писања страних речи, личних имена и географских назива, као и низа других правила. 
тј. положај између православног и католичког света условио је преплитање различитих утицаја и традиција током историје земље. Додатна отежавајућа околност је да Белорусија више векова није имала своју државу, а самим тим ни националну језичку политику, а белоруски језик је више пута забрањиван од стране Пољске и царске Русије (у 17, 18. и 19. веку).

Писмо је представљало управо инструмент једног или другог утицаја током историје земље. Римокатолички утицај (пре свега пољски) и контакти са суседима одразили су се на шире коришћење латинице код Белоруса (посебно у 17-18. веку, делимично у 19. веку, као и у периоду 1921-1939. год. у Западној Белорусији). Период Белорусије у саставу царске Русије и СССР-а учврстио је положај ћирилице (19-20. век). Језичка политика окупационе немачке владе у Белорусији за време Првог и Другог светског рата подразумевала је увођење латинице, пре свега у циљу смањења руског утицаја.

Представници националног покрета, познати писци и издавачи у 19. веку и почетком 20. века, а касније научници и други интелектуалци током двадесетих година 20. века, имали су подељена мишљења о избору писма и низу правописних питања белоруског књижевног језика. Ипак, већина се определила за изворно ћирилично писмо, што су показале анкете у новинама, као и друге јавне расправе, научни скупови, укључујући и чувену Академску конференцију 1926. године. Ти догађаји су показали да је од значаја и став интелектуалаца, глас сваког од њих.

У данашње време већина Белоруса доживљавају ћирилицу као своје изворно писмо и пишу искључиво ћирилицом. Латиница је слабо заступљена, без обзира на утицај Интернета и мобилне телефоније. Може се рећи да ћирилица у Белорусији има чврст положај и заштићена је самим ставом и односом народа према свом писму.

Анализом важних чињеница издвојили смо основне факторе који су током историје утицали, али и сада могу да утичу, на националну свест о избору писма, а то су: изворност писма, средњовековна традиција, контакти и страни утицаји, државна политика, став интелектуалаца, тј. представника националних покрета, као и однос народа према писму. Историја указује да писмо представља важан инструмент ширења утицаја, као и средство супротстављања одређеном утицају, средство издвајања у односу на традицију која тренутно доминира. Писмо је непроцењиво важан део националног идентитета и културно-историјског развоја народа.

\section{ЛИТЕРАТУРА}

Анђелковић 2009: Драгомир Анђелковић, Историја Белорусије, Београд.

Белакурская 2005: Жанна Я. Белакурская, Графічныя асаблівасці рукапіснага і друкаванага варыянтаў зборніка Якуба Коласа „Другое чытанне для дзяцей беларусаў”, Беларуская мова: хрэстаматыя, Мінск, 42-49.

Гісторыя 2004: Гісторыя беларускага мовазнаўства, Мінск. 
Запрудскі 2015: Сяргей М. Запрудскі, Гісторыя беларускага мовазнаўства (1918-1941), Мінск.

Кожинова 2017: Алла А. Кожинова, Языки и графические системы Беларуси в период от Октябрьской революции до Второй мировой войны, Studi slavistici, XVI, 133-156.

Лепешаў 2005: Іван Я. Лепешаў, Сучасная беларуская літаратурная мова: спрэчныя пытанні, Беларуская мова: хрэстаматыя, Мінск, 37-42.

Мячкоўская 2005: Ніна Б. Мячкоўская, Навошта аднаму народу дзве азбукі? (Кіріліца і лацінка ў калізіях беларускага Адраджэння), Беларуская мова: хрэстаматыя, Мінск, 34-36.

Парашкоў 2003: Сяргей А. Парашкоў, Гісторыя культуры Беларусі, Мінск.

Светлана Голяк

\section{КИРИЛЛИЦА И ЛАТИНИЦА В УКРАИНСКОЙ ОРФОГРАФИИ: ИСТОРИЧЕСКИЙ И СОВРЕМЕННЫЙ ОБЗОР}

Резюме

Кириллица является первой азбукой белорусов как в рукописной традиции, так и в первых печатных книгах Франциска Скорины. На кириллице в XIV-XVI веках составлена бо́льшая часть юридических и деловых документов на старобелорусском языке, в том числе Устав Великого княжества Литовского, в состав которого входили белорусские земли.

Однако далее в ходе истории в Беларуси использовалась как кириллица, так и латиница вследствие географического положения между православным и католическим миром и соответствующего влияния и контактов. После унии Великого княжества Литовского с соседней Польшей в 1569 году и создания Речи Посполитой усиливается западное влияние на белорусской территории, расширяется использование латиницы, особенно в XVII-XVIII веках. После вхождения белорусских земель в состав Российской империи в XIX веке, а позже в XX веке в состав СССР укрепляется положение кириллицы.

Письмо, таким образом, служило инструментом расширения того или иного влияния, а также средством противостояния ему и отделения от доминантной традиции.

Представители национального движения в XIX веке и в первые десятилетия XX века использовали как кириллицу, так и латиницу. Первые печатные белорусские издания в XIX и начале XX века вышли на латинице. Первые книги писателей и поэтов, сыгравших важную роль в формировании белорусского литературного языка, напечатаны на кириллице или на латинице. Первые грамматики и орфографические пособия вышли на латинице. Все это обусловило неоднозначную ситуацию по вопросу выбора письма в двадцатые годы XX века, когда, наряду с государственной политикой, важными факторами являлись мнение интеллигенции и отношение народа. Большинство ученых, представителей интеллигенции высказались за кириллицу, в том числе на известной Академической конференции 1926 года.

После Второй мировой войны латиница в ряде случаев использовалась эмиграцией. В девяностые годы наблюдался повышенный интерес к латинице. В наше время кириллица занимает прочные позиции, несмотря на влияние Интернета и современных средств связи.

История позволяет выделить и учесть все факторы, которые влияли и могут влиять на национальное сознание и отношение к выбору письма. К важнейшим факторам следует отнести: истоки письменности, средневековые традиции, а также традиции национального возрождения; контакты и факторы влияния (западного или восточного), включая политику оккупационных властей; наличие государственности и языковую политику, позицию интеллигенции и отношение народа к своему письму. 